J-DEPACE, Volume 4, Nomor 1, Juni 2021, Hal 21-30

Tersedia online di :http://jurnal.lpmiunvic.ac.id/index.php/jpkm

\title{
BAHAGIA DAN KREATIF, ITU PILIHAN! (Pengabdian Kepada Masyarakat Lewat Belajar dan Bermain, untuk Usia Anak dan Remaja)
}

\author{
Sherly Gaspersz, ${ }^{1}$ Natasya Virginia Leuwol, ${ }^{2}$ Melda A.Manuhutu, ${ }^{3}$ Lulu Jola Uktolseja, ${ }^{4}$ \\ Tagor Manurung, ${ }^{5}$ Jalmijn Tindage, ${ }^{6}$ Windy Wonmally, ${ }^{7}$ Ferdinando Solissa, ${ }^{8}$ \\ Universitas Victory Sorong \\ ${ }^{1}$ sherlygaspersz91@gmail.com 2natasya.leuwol@gmail.com, ${ }^{3}$ melda.a.manuhutu@gmail.com,, \\ ${ }^{4}$ lulujola39@gmail.com, ${ }^{5}$ tagormanurung24031963@gmail.com, \\ 6jalmijn@unvicsorong.ac.id, ${ }^{7}$ wwonmally@gmail.com, ${ }^{8}$ ferdinandosolissa282@gmail.com
}

\begin{abstract}
ABSTRAK
Kebahagiaan dan Kreatif adalah sebuah pilihan hidup manusia. Lewat Pikiran yang positif dapat menghasilkan sesuatu yang kreatif dan bermakna, sehingga mampu termotivasi untuk melakukan banyak hal. Mendapat sebuah kebahagiaan butuh keaktivan atau usaha, kita tidak bisa diam saja, itu artinya pengembangan diri itu perlu dilakukan. Seringkali kita berpikir untuk memperoleh kebahagiaan itu sulit, namun ternyata kebahagiaan dapat diperoleh dengan kegiatan atau aktivitas yang sederhana. Hal ini bisa terjadi karena kebahagiaan adalah perilaku penyesuaian terhadap keluarga, sesama, lingkungan dan bisa dipelajari oleh siapa saja. Berdasarkan asumsi diatas, simpulan yang kami dapati dari pelaksanaan PKM di kedua tempat bahwa, kebahagiaan adalah sesuatu yang harus diusahakan, diperjuangkan dengan dimulai dengan diri kita sendiri dengan melakukan hal-hal kecil yang dapat menyenangkan hati dan orang lain.
\end{abstract}

Kata kunci: kebahagiaan, perilaku adaptif kreatif, perilaku belajar, pengalaman mengalir

\begin{abstract}
Happiness and creativity are choices of human life. Through positive thoughts, you can produce somethingcreative and meaningful, so you can be motivated to do many things. Getting a happiness requires activity or effort, we can not just stand, that means self development needs to be done. Often we think that finding happiness is difficult, but it turns out that happiness can be obtained with simple activities. This can happen becahse happiness is an adjustment behavior towards family, others, the environment and can be learned by anyone. Based on the assumptions, the conclusion we got from the implementation of PKM in both places is that happiness is something that must be strived for, fought by starting with ourselves by doing small things that can please the heart and others..
\end{abstract}

Key words: happiness, adaptive behavior, learned behavior, flow experiences 


\section{PENDAHULUAN}

Bahagia atau kebahagiaan itu selalu didambakan atau dicari oleh setiap insan. Pada zaman modern ini kebahagiaan itu masih tetap dicari. Yang menjadi sebuah persoalan adalah, kebahagiaan selalu dicari oleh siapa pun, baik itu anak kecil, orang tua, perempuan, laki-laki, orang yang berpendidikan tinggi, menengah maupun atas, orang kaya, orang miskin, semuanya pasti mau hidupnya bahagia.

Kebahagiaan memiliki arti yang berbeda beda jika ditinjau dari arti kata yang ada di berbagai belahan dunia, antara lain bahagia dalam Bahasa Jerman adalah Gluck, Bahagia dalam Bahasa Inggris adalah Happiness, dan dalam Bahasa Bahasa China adalah Xing Fu. Kesemua arti tersebut, menunjuk "keberuntungan, kesuksesan, kesenangan, dan nasib baik.

Gambaran kebahagiaan bagi masing-masing orang pun berbeda. Dalam sebuah Refleksi ketika kami melakukan Pengabdian kepada masyarakat di PAR Jemaat GKI Selebesolu dan Panti Asuhan Bukit Hermon, Kota Sorong, Papua Barat, kami bertanya kepada anak-anak, apa arti kebahagiaan ?, sebagian besar menjawab, bahagia jika bersama dan berkumpul temanteman, ada yang bahagia ketika bisa memiliki mobil, bisa kembali ke sekolah, bahagia jika bisa jadi orang sukses, dan lain sebagainya.

Dalam Refleksi yang berbeda, kami bertanya, kalau misalkan, adik-adik, waktu yang Tuhan berikan hidup di dunia ini hanya tinggal 3 hari, apa yang akan adik-adik lakukan ? ada yang mengatakan bahwa, yang mereka akan mencari kesenangan sepuas-puasnya, ada yang mengatakan bahwa mereka akan menangis dan takut, ada yang mengatakan untuk minta maaf kepada orang tua, dan ada yang mengatakan akan melakukan suatu hal yang belum dilakukan ketika ia hidup, dan lain sebagainya.

Menurut Aristoteles, salah satu Filsuf, bahwa kebahagiaan itu lebih dari kesenangan fisik, dan itu didukung oleh filsuf lainnya, seperti kaum Hedonis dan Utilitarian yang mengatakan bahwa kebahagiaan bukan hanya diukur dari sebuah hal yang merupakan kesenangan semata, namun kebahagiaan juga dapat diperoleh dari sebuah perjuangan yang beresiko dan sulit. Selain itu juga, kebahagiaan juga dapat diperoleh dari sikap hidup yang buruk atau sikap hidup yang tidak bermoral, contoh ; orang senang karena melakukan korupsi, penipuan dan lain sebagainya, hal ini membuat pelaku bahagia, sedangkan korban menjadi menderita. 
Berbagai kontradiksi tampak dalam kenyataan sehari-hari. Kebahagiaan sebagai emosi positif di kehidupan masa anak sampai dengan masa remaja adalah bagaimana ia mengembangkan kemampuan untuk beradaptasi dengan lingkungan sosial dimana mereka ada. Selain itu kebahagiaan masa anak dan remaja dalam upaya mencapai kepribadian yang sehat untuk mendukung pemenuhan tugas perkembangannya. Kebahagiaan sangat mempengaruhi perkembangan seseorang khususnya anak, khususnya pada aspek pribadi dan sosialnya.

Kebahagiaan membantu terbentuknya kepribadian yang sehat serta kehidupan sosial yang baik. Kebahagiaan sebenarnya sangat luas, namun yang dimaksudkan disini adalah kebahagiaan yang pernah dan telah dirasakan maupun kebahagiaan yang masih dalam anganangan pikiran. Alasan mengapa diambilnya tema ini dalam PKM kami, karena kebahagiaan sebenarnya setiap hari telah banyak dirasakan dan selalu melekat pada kehidupan sehari-hari, jadi dengan belajar sambil bermain, sangat membantu perkembangan anak dan remaja. Berdasarkan pengalaman-pengalaman tentang kebahagiaan, tim ingin memvisualisasikan dalam bentuk kreatifitas dengan teknik belajar dan bermain.

Tim akan mewujudkan karya-karya tersebut secara berurutan sesuai pengalaman kebahagiaan dan kreatifitas yang tim alami didalam proses perkuliahan dalam mata kuliah etika kristen pada program studi di Fakultas Keguruan Ilmu Pendidikan yaitu Program studi Pendidikan Bahasa \& Sastra Indonesia. Dan Program studi Pendidikan Bahasa Inggris.

\section{MASALAH}

Berdasarkan Pengamatan di lapangan, ditemukan ternyata dampak pandemi Covid 19 yang belum berakhir, dengan peraturan social distanding yang masih diterapkan dalam aktivitas yang dibatasi, baik aktivitas pendidikan, perkantoran, peribadatan dan lain sebagainya.Kondisi ini membuat anak-anak sulit bermain secara bebas, belajar lebih kepada belajar secara virtual, dan adanya kecemasan atau ketakutan di dalam berinteraksi antar sesama seperti biasanya. Hal-hal inilah yang menjadi masalah, khususnya bagi perkembangan anak, baik secara mental dan spritualnya. Oleh karena itu, kami Tim PKM merasa penting, untuk menghadirkan kegiatan yang dapat memberi suasana kebahagiaan dan sekaligus mengembangkan kreatifitas anak dan Remaja, khususnya di PAR jemaat GKI Sele be solo dan 
Panti Asuhan Bukit Hermon, Kota Sorong, Papua Barat.

\section{METODE}

Metode pelaksanaan kegiatan PKM untuk menyelesaikan permasalahan-permasalahan mitra menggunakan metode pendekatan dalam bentuk Belajar sambil bermain. Permasalahanpermasalahan yang akan diselesaikan antara lain : Pemilihan Materi dan metode belajar dan bermain yang tepat bagi anak dan remaja guna menikmati kebahagiaan dan kreatifitas di dalam kehidupan. Pengembangan Karakter anak dan remaja yang baik berdasarkan iman Kristen. Minimnya pengetahuan guru sekolah minggu dalam Hal ini Persekutuan anak sekolah minggu di gereja-gereja dan bagi pembina panti asuhan tentang media pembelajaran yang inovatif, di masa pandemic covid 19, sehingga metode yang dipakai adalah melalui beberapa tahapan, yaitu ; tahapan persiapan, tahapan pelaksanaan dan tahapan evaluasi.

\section{PEMBAHASAN}

Ada banyak Mitos tentang kebahagiaan, orang berpikir bahwa kebahagiaan dapat dirasakan jika ada meraih kesuksesan, kekayaaan, jika terkenal, hal ini diungkapkan oleh Franken tahun 2022, ia meneliti dan diketahui bahwa ternyata kebahagiaan dapat dimiliki oleh semua orang. Ada juga penelitian oleh, Inglehart dan juga didukung oleh Myers, didalam penelitian mereka menggunakan 169,776 ribu sampel dari 16 negara, dan hasilnya menunjukan bahwa $80 \%$ kaum laki-laki dan kaum perempuan berkata bahwa mereka sangat bahagia, karena sangat puas memiliki kehidupan yang saat ini mereka jalani dan mereka raih. Mitos lain tentang kebahagiaan adalah, bahagia jika mereka punya uang banyak, sehingga banyak orang yang menghabiskan waktunya untuk menghasilkan uang, ada yang mengatakan bahagia jika masuk universitas atau jika membeli perumahan di kompleks elite. Namun, semua itu bukanlah sebuah ukuran atau standar sebuah kebahagiaan manusia, walaupun tidak bisa kita pungkiri, kita sangat menginginkan dan membutuhkan semuanya.

Banyak kasus yang dapat kita lihat, orang yang terkenal, orang yang terkaya, orang yang 
terpintar sekalipun tidaklah menjamin kebahagiaan itu akan menetap dengan lama, terbukti ada dari mereka yang ditemukan meninggal bunuh diri, terlibat kasus narkoba (obat-obat terlarang), dan lain-lain, itu artinya kebahagiaan harus dimaknai secara baik, dan tergantung orang yang memaknainya di dalam hidup.

Kebahagiaan menurut Buss dalam Franken 2002 adalah sebuah perilaku penyesuaian mendasar terhadap lingkungan sosial yang bermakna. Hal tersebut dapat diperoleh dengan 8 cara, yaitu:

1) Seseorang memiliki kehidupan yang sehat

2) Seseorang memiliki kesuksesan secara professional

3) Seseorang yang dapat membantu teman dan kerabat.

4) Seseorang yang dapat memiliki hubungan atau intimate yang baik dengan orang lain

5) Seseorang yang dapat mengekspresikan Rasa percaya diri untuk membantu meraih kesuksesan

6) Seseorang yang dapat menikmati makanan yang lezat

7) Seseorang yang memiliki banyak hal dalam hidup

8) Seseirang yang dapat menikmati hidup apa adanya.

Sedangkan menurut, Arkoff, ada 3 hal yang dapat diraih untuk mendapatkan kebahagiaan, yaitu;

1) Keluarga

2) Kesehatan

3) Keberadaan orang-orang yang dikasihi

Ketiga sumber ini, tidak harus ketiganya dimiliki, jika salah satu dapat diraih pun kebahagiaan sudah didapatkan. Hal ini yang dikatakan, bahwa kebahagiaan dapat didapatkan dengan hal-hal yang kecil atau sederhana di dalam kehidupan kita manusia.

Kebahagiaan dapat dipelajari secara kognitif manusia, yaitu belajar untuk memperoleh sesuatu, belajar untuk melakukan sesuatu, belajar untuk melupakan sesuatu, dan lain sebagainya.Berdasarkan pengalaman-pengalaman di dalam kehidupan itulah, manusia dapat menjadi bahagia, karena ia dapat mengetahui dan menentukan kebahagiaan seperti apa yang hendak ia raih di dalam hidupnya sebagai manusia.Veenhoten (1994) mengatakan bahwa kebahagiaan adalah suatu variabel yang biasa, sehingga dapat untuk dipelajari dan dapat 
disesuaikan sedemikian rupa agar manusia dapat memilikinya. Contoh ; dengan melakukan hal-hal yang sederhana, dengan cara yang kreatif, sehingga dapat membuat kesengan bersama, seperti bermain, nonton bersama, belajar bersama, dan lain sebagainya.

Kebahagiaan bukanlah milik satu orang saja, tetapi kebahagiaan adalah milik universal. Oleh karena itu, manusia termotivasi untuk terus membuat rencana, untuk menggapai kebahagiaan dalam hidup. Hal itu menjadi regenerasi yang terus berlanjut dari generasi satu ke generasi lainnya, sebagai suatu proses "shared fate".

Kreatifitas adalah sebuah tindakan yang bernilai seni, yang dpat mengembangkan diri dan orang lain. Orang yang mampu melakukan kreatifitas dalam hidup mereka, sudah pasti orang tersebut bahagia, karena ia mampu ada di dalam situasi yang tenang dan mengalir potensipotensi yang ada didalam dirinya dapat dikeluarkan menjadi hal yang bernilai.

Kondisi kegiatan yang mengalir oleh seseorang secara aktif dan larut dalam kegiatan yang menyenangkan sehingga memperoleh sebuah kepuasan dan kebahagiaan, maka orang itu akan mampu melakukannya secara terus menerus. Franken, tahun 2002 mengatakan bahwa kebahagiaanakan menajadi kuat, jika seseorang mampu beraktivitas untuk menggali akan pikirannya dengan baik. Orang-orang yang demikian, menurut, Massimini dan Charli, di dalam Chen, Wigand dan Nilan, 2000, mereka mengatakan bahwa, usia anak dan remaja, dapat mengalami pengalaman-pengalaman yang mengalir begitu saja, sehingga mereka bebas, dan jauh dari rasa takut, seperti yang dimiliki oleh orang dewasa, karena anakanak dan remaja masih dalam kehidupan yang masih polos, mereka menikmati kebersamaan denga tertawa bersama, bermain bersama, belajar bersama, beraktivitas bersama, dan lain sebagainya, dan hal inilah yang memenuhi mereka dengan emosi-emosi yang positif, sehingga mereka merasakan adanya kebahagiaan didalam hidup mereka.

Kebahagiaan Pada Akhirnya Adakah manusia bisa memancarkan ekspresi yang begitu nampak ketika kami ada dalam aktivitas PKM Bersama anak dan remaja di PAR Wik 8 Jemaat GKI Bethesda Selebesolo dan Panti asuhan Bukti Hermon. Pada akhirnya kebahagiaan adalah seperti aliran sungai yang berkelok-kelok dan memiliki muara yangberbeda-beda. Dan semua itu Nampak dari ekspresi yang ditunjukan oleh masing-masing anak, maupun kami sebagai tim dan mahasiswa dari kedua program studia yang ada. Yang jelas, untuk mendapatkan 
Sherly Gaspersz, dkk

Bahagia Dan Kreatif, Itu Pilihan!

(Pengabdian Kepada Masyarakat Lewat Belajar dan Bermain, untuk Usia Anak dan Remaja..

kebahagiaan seseorang harus memulai langkah awal dengan sesuatu yang dinamakan cinta, dan memiliki kepekaan dan kemampuan beradaptasi secara sosial. Karena manusia adalah makluk individu dan juga makluk sosial. Berbahagia adalah ketika kita bisa menerima diri kita apa adanya, dan menerima orang lain didalam kehidupan kita, namun didalam sebuah kontrol diri yang baik (Buss, 2001). Selain itu juga, menurut penelitian dari Blakeslee dan Grossarth di dalam Heylighen, 1999 mengatakan bahwa orang yang bahagia, memiliki kecendrungan memiliki ketahanan tubuh yang baik, dan tidak mudah sakit, dibandingkan dengan orang yang hidupnya tidak bahagia. Pada kenyataannya mungkin memang tidak sesederhana itu, namun sesungguhnya dapat terlihat jelas bahwa untuk menjadi manusia yang bahagia akan jauh lebih bermanfaat danri pada orang yang tidak bahagia.

Sekarang tinggal manusia yang menjalani hidupnya untuk memilih menjadi bahagia dengan berusaha mendapatkannya dengan kreatif atau tetap tenggelam di dalam sebuah kehidupan yang sengsara dan penuh kepahitan.

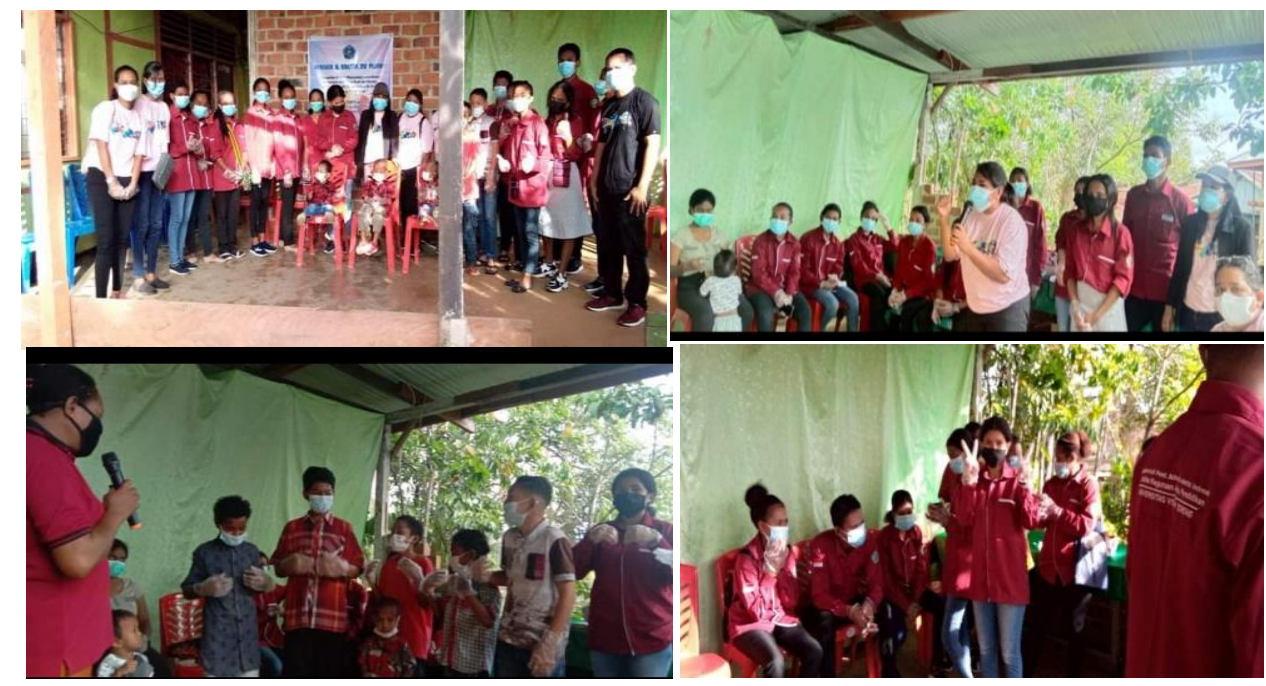

Gambar 1. PKM di PAR Wik 8, GKI Jemaat Bethesda Sele be solo, Kota Sorong, Tim dengan mahasiswa Program studi Pendidikan dan Sastra Bahasa Indonesia, Universitas Victory Sorong
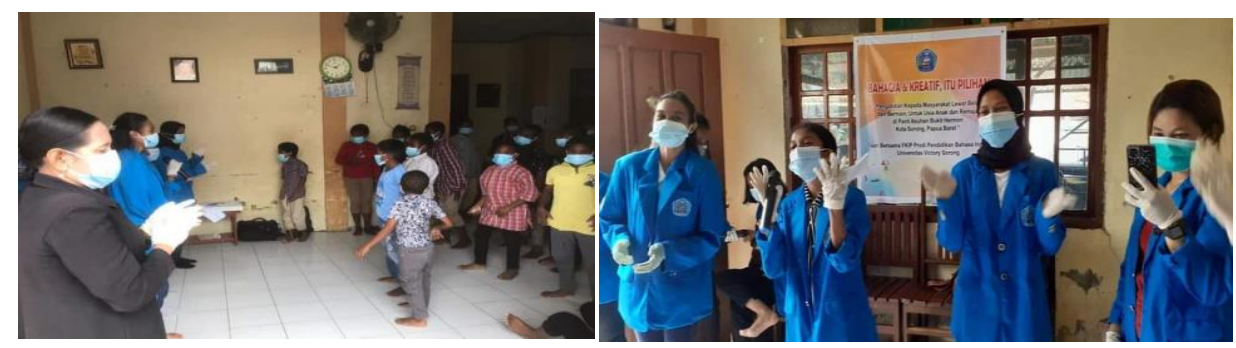


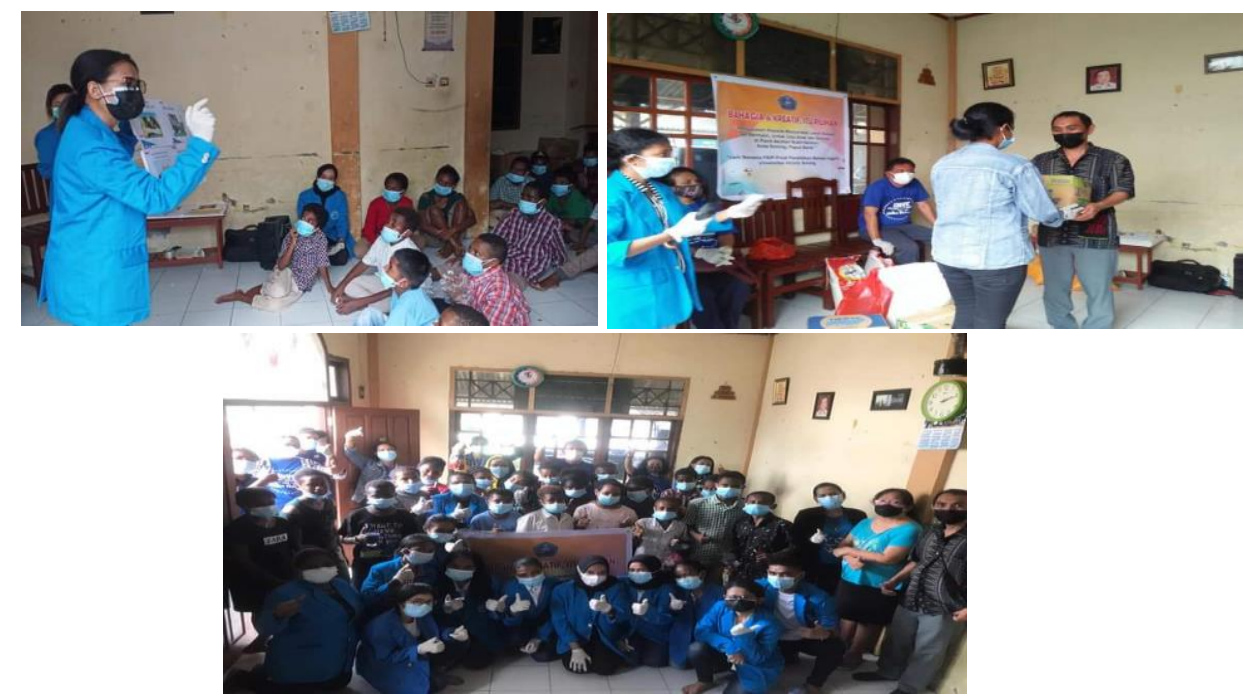

Gambar 2. PKM di Panti Asuhan Bukit Hermon. Kota Sorong, Tim dengan mahasiswa Program studi Pendidikan Bahasa Inggris, Universitas Victory Sorong

\section{KESIMPULAN}

Kebahagiaan adalah milik semua orang (universal), kebahagiaan adalah sebuah Anugerah Tuhan yang harus kita syukuri dan kita dinikmati. Kebahagiaan harus dapat mengalir di dalam diri kita, kita yang harus bisa menikmati segala aktivitas hidup yang ada, artinya kebahagiaan tidak terjadi begitu saja, kebahgaiaan bukanlah khayalan atau mimpi, akan tetapi kebahagiaan harus diupayakan dengan berbagai cara didalam kehidupan kita sebagai manusia.

Kebahagiaan dapat dilakukan dengan cara-cara yang menyenangkan dan kreaif, melalui hal-hal yang bersemangat, menantang, hal-hal yang disenangi, hal-hal yang bernilai positif, dalam sebuah hubungan interaksi sosia, sehingga terbina hubungan kekerabatan, persahabatan yang mendalam, keeratan di dalam lingkungan keluarga, dan dimanapun kita berada.Hal-hal tersebut dapat dilakukan dengan cara ; belajar bersama, bermain bersama, bernyanyi bersama, tertawa bersama, dan lain sebagainya, sehingga dapat membantu manusia didalam memperoleh yang namanya kebahagiaan hidup. 


\section{DAFTAR PUSTAKA}

Arkoff, A. 1975. Psychology and personal growth. Boston: Allyn and Bacon.

Beck, R.C. 1990. Motivation: Theories and principles (third edition). New Jersey: Prentice Hall.

Benokraitis, N.J. 1996. Marriages and families: Changes, choices and constraints (second edition). New Jersey: Prentice Hall.

Buss, A. 2001. Psychological dimensions of the self. California: SAGE Publications, Inc.

Chen, H., Wigand, R.T \& Nilan, M. 2000. Exploring web users' optimal flow experiences. Information Technology \& People, 13, pp. 263-281.

Craig, G.J. 1992. Human development (sixth edition). New Jersey: Prentice Hall.

Duck, S. 2000. Human relationship (third edition). London: SAGE Publication Inc.

Dalgleish, T., \& Power, M. 1999. Handbook of cognition and emotion. Chichester: John Wiley \& Sons, Ltd.

Departemen Pendidikan dan Kebudayaan. 1990. Kamus besar bahasa Indonesia. Jakarta: Balai Pustaka.

Franken, R.E. 2002. Human motivation (fifth edition). Belmont: Wadsworth.

Harre, R., \& Parrot, W.G. 2000. The emotion: Social, cultural and biological dimensions. London : SAGE Publications, Inc.

Hendrick, C., \& Hendrick S.S. 2000. Close relationship: A sourcebook. California: SAGE Publication, Inc.

Heylighen, F. 1999. Happiness. http://pespmc1.vub.ac.be/HAPPINES. html.

Lupton, D. 1998. The emotional self.

London: SAGE Publications, Inc.

Mills, R., \& Duck, S. 2000. The developmental psychology of personal relationship. Chichester: John Wiley \& Sons, Inc.

Maslow, A. 1993. Motivasi dan kepribadian 2: Teori motivasi dengan pendekatan hierarki kebutuhan manusia (edisi kedua). Alih Bahasa: Nurul Imam. Jakarta: Pustaka Binaman Pressindo.

Maxwell, J.C. 2001. Harta karun persahabatan. Alih Bahasa: Merry Sutedja. Jakarta: Mitra Media. 
Myers, D.G. 1994. Exploring social psychology. New Jersey: McGraw- Hill, Inc.

Pearson, J.C. 1983. Interpersonal communication: clarity, confidenceconcern. Glenview: Scott, Foresman and Company.

Prager, K.J. 1995. The psychology of intimacy. New York: The Guildford Press. 